\title{
Microbial Inventory of Deeply Buried Oceanic Crust from a Young Ridge Flank
}

\author{
Steffen L. Jørgensen * and Rui Zhao \\ Department of Biology, Centre for Geobiology, University of Bergen, Bergen, Norway
}

The deep marine biosphere has over the past decades been exposed as an immense habitat for microorganisms with wide-reaching implications for our understanding of life on Earth. Recent advances in knowledge concerning this biosphere have been achieved mainly through extensive microbial and geochemical studies of deep marine sediments. However, the oceanic crust buried beneath the sediments, is still largely unexplored with respect to even the most fundamental questions related to microbial life. Here, we present quantitative and qualitative data related to the microbial inventory from 33 deeply buried basaltic rocks collected at two different locations, penetrating 300 vertical meters into the upper oceanic crust on the west flank of the Mid-Atlantic spreading ridge. We use quantitative PCR and sequencing of $16 \mathrm{~S}$ rRNA gene amplicons to estimate cell abundances and to profile the community structure. Our data suggest that the

OPEN ACCESS

Edited by: Beth Orcutt, Bigelow Laboratory for Ocean Sciences, USA

Reviewed by: William Brazelton, East Carolina University, USA Hazel Barton,

University of Akron, USA

*Correspondence:

Steffen L. Jørgensen steffen.jorgensen@bio.uib.no

Specialty section: This article was submitted to

Extreme Microbiology, a section of the journal Frontiers in Microbiology

Received: 09 January 2016 Accepted: 13 May 2016 Published: 27 May 2016

Citation: Jørgensen SL and Zhao R (2016) Microbial Inventory of Deeply Buried Oceanic Crust from a Young Ridge

Flank. Front. Microbiol. 7:820. doi: 10.3389/fmicb.2016.00820 number of cells is relatively stable at $\sim 10^{4}$ per gram of rock irrespectively of sampling site and depth. Further, we show that Proteobacteria, especially Gammaproteobacteria dominate the microbial assemblage across all investigated samples, with Archaea, in general, represented by $<1 \%$ of the community. In addition, we show that the communities within the crust are distinct from the overlying sediment. However, many of their respective microbial inhabitants are shared between the two biomes, but with markedly different relative distributions. Our study provides fundamental information with respect to abundance, distribution, and identity of microorganisms in the upper oceanic crust.

Keywords: deep biosphere, oceanic crust, geobiology, cell abundance, community structure, endolitihic community

\section{INTRODUCTION}

Every day $\sim 100$ billion cubic meters of bottom seawater are transported down into the permeable upper oceanic crust. Within this gigantic aquifer system oxic seawater circulates and reacts with reduced igneous rocks before eventually recharging back into the oceans $10^{3}-10^{4}$ years later (Wheat et al., 2003; Orcutt et al., 2011). Consequently, the chemical composition of fluids and rocks are strongly altered, with wide-reaching ramifications throughout the marine system (Fisher and Becker, 2000; Bach and Edwards, 2003; Bach et al., 2004). Strong evidence exist for an abundant microbial community residing within this subsurface crustal basaltic aquifer (Giovannoni et al., 1996; Torsvik et al., 1998; Fisk et al., 2003; Lysnes et al., 2004; Orcutt et al., 2011; Nigro et al., 2012; Lever et al., 2013) where microbial activity is believed to influence basalt alteration and mineral dissolution 
rates (Thorseth et al., 1995; Fisk et al., 1998; Furnes et al., 2001b; Storrie-Lombardi and Fisk, 2004; Kruber et al., 2008).

Endolithic microorganisms in subsurface basalt were first reported two decades ago from a drilling expedition to the Costa Rica Rift zone (Ocean Drilling Program Leg, ODP Leg 148). The presence and activity of microorganisms were inferred via detection of biosignatures including: (i) microscopic tubular structures in which DNA could be detected by staining (Thorseth et al., 1995; Giovannoni et al., 1996), (ii) targeting and localization of intact and active cells via in situ fluorescent hybridization (FISH) (Torsvik et al., 1998), and (iii) sitespecific nitrogen and carbon enrichment in the altered tubular structures (Giovannoni et al., 1996; Torsvik et al., 1998). These results were later supported by drilling in the Australian Antarctic Discordance (ODP Leg 187) where, in addition to corroborating textural, geochemical, and molecular observations (Furnes et al., 2001a,b; Thorseth et al., 2003), microbial DNA (16S rRNA genes) from subsurface samples was for the first time successfully amplified and sequenced (Lysnes et al., 2004). Despite limited sequencing depth, this analysis revealed a unique microbial population dominated by the bacterial phyla Gammaproteobacteria, Actinobacteria, Bacteroidetes, Chloroflexi, and Firmicutes, and different from those in the above sediment and seawater.

Besides the pioneering work outlined above only a few additional microbial studies have directly investigated native subsurface igneous rocks (Fisk et al., 2003; Mason et al., 2010; Lever et al., 2013; Orcutt et al., 2015). Thus, this habitat is heavily under-studied, a fact that can be largely attributed to the immense technical and economic challenges involved in the sampling of deeply buried oceanic crust. Consequently, most of our knowledge about the crustal biosphere originates from samples exposed at the seafloor (Orcutt et al., 2011; Edwards et al., 2012b; Orcutt and Edwards, 2014). Seafloor-derived samples, however, are not representative of the subseafloor crustal environment and constitute only a small fraction of the $10^{9} \mathrm{~km}^{3}$ of the upper oceanic crust that has been suggested to be habitable (Heberling et al., 2010). In an effort to address these concerns, in situ subseafloor observatories, installed primarily at Juan de Fuca Ridge (JdFR), have expanded our understanding of subseafloor water-rock-microbe interactions in a more representative setting (Orcutt et al., 2011). Despite such technological advancement, a number of basic questions cannot easily be inferred from subseafloor observatories, including cell abundances and community structure in native material.

The first dedicated microbial investigation of a lowtemperature young ridge flank system was undertaken by the International Ocean Drilling Program (IODP) expedition 336 to North Pond in the North Atlantic gyre (Expedition 336 Scientists, 2012e). The basement in North Pond is covered by a sediment layer (up to $300 \mathrm{~m}$ ) and is characterized by vigorous crustal fluid circulation driven mainly by advection (Edwards et al., 2012a). The fast fluid circulation results in relatively low fluid temperatures $\left(10-15^{\circ} \mathrm{C}\right)$ and seawater-like fluid chemistry, such as high dissolved oxygen concentration at discharge zones [55$191 \mu \mathrm{M}$ ] (Orcutt et al., 2013). Further, a recent study revealed an active and distinct bacterial community in the crustal fluids underneath North Pond (Meyer et al., 2016).

In the present study, we analyse the abundance and structure of microbial communities in deeply buried basaltic rocks in a total of 33 different samples retrieved from the basement underneath North Pond and compare these to the communities in the above sediments. We analyse the samples by means of 16S rRNA gene amplicon libraries and quantitative PCR (qPCR). Our results are among the first to quantify microbial abundances in native subsurface basalt, thus guiding biomass constrains for this globally significant system. Furthermore, our data elucidate the taxonomic identity of native microbial inhabitants suggesting a community capable of facilitating a diverse range of redox reactions. Lastly, we provide evidence that the dispersal scenarios of the sedimentary and crustal microbial inhabitants are intertwined and potentially closely linked.

\section{MATERIALS AND METHODS \\ Sample Location, Collection, and Description}

We investigated a total of 33 subsurface samples ( 27 from igneous crust and 6 from a sedimentary breccia) collected from North Pond on the west flank of the Mid-Atlantic Ridge. Samples originate from Holes $1382 \mathrm{~A}\left(22^{\circ} 45.353^{\prime} \mathrm{N}, 46^{\circ} 04.891^{\prime} \mathrm{W}\right)$ and $1383 \mathrm{C}\left(22^{\circ} 48.1241^{\prime} \mathrm{N}, 46^{\circ} 03.1662^{\prime} \mathrm{W}\right.$; Figure 1), both were retrieved using rotary core barrel (RCB) coring. Florescent microspheres were added to the drilling fluid in order to assess potential contamination as described in details elsewhere (Expedition 336 Scientists, 2012d). In order to remove potential contamination introduced during drilling operation, all samples were washed three times in sterile seawater on-board before being sub-sampled into smaller pieces using a chisel and hammer under sterile conditions, as described in details elsewhere (Expedition 336 Scientists, 2012c). The presence of fluorescent microspheres in the wash solution was investigated by microscopy after the last wash. Subsamples $\left(\sim 2 \mathrm{~cm}^{3}\right)$ were placed in sterile Whirlpak bags and immediately frozen at $-80^{\circ} \mathrm{C}$ before further processing at the home institute.

Samples follow a depth gradient ranging from $\sim 110$ to 200 meter below seafloor (mbsf) in Hole 1382A (16 samples) and 70 to 300 mbsf in Hole 1383C (17 samples). The igneous crust at the two sites likely originates from different volcanic centers fed by a mantle source of variable composition (Expedition 336 Scientists, 2012c). A short overview of sample depths and lithological characteristics can be found in Table 1. For a comprehensive description the reader is recommended to consult the IODP proceedings volume 336 (http://publications.iodp.org/proceedings/336/336title.htm). Following is a brief characterization of each site.

In Hole 1382A basement was located 90 mbsf, however the interval from 93 to $99 \mathrm{mbsf}$ are inferred to be sedimentary (Expedition 336 Scientists, 2012e). A total of 32 meter of upper crustal material was recovered between 110 and 210 mbsf (recovery 32\%). From this material we analyzed 16 samples covering six of the eight lithological units encountered in this 


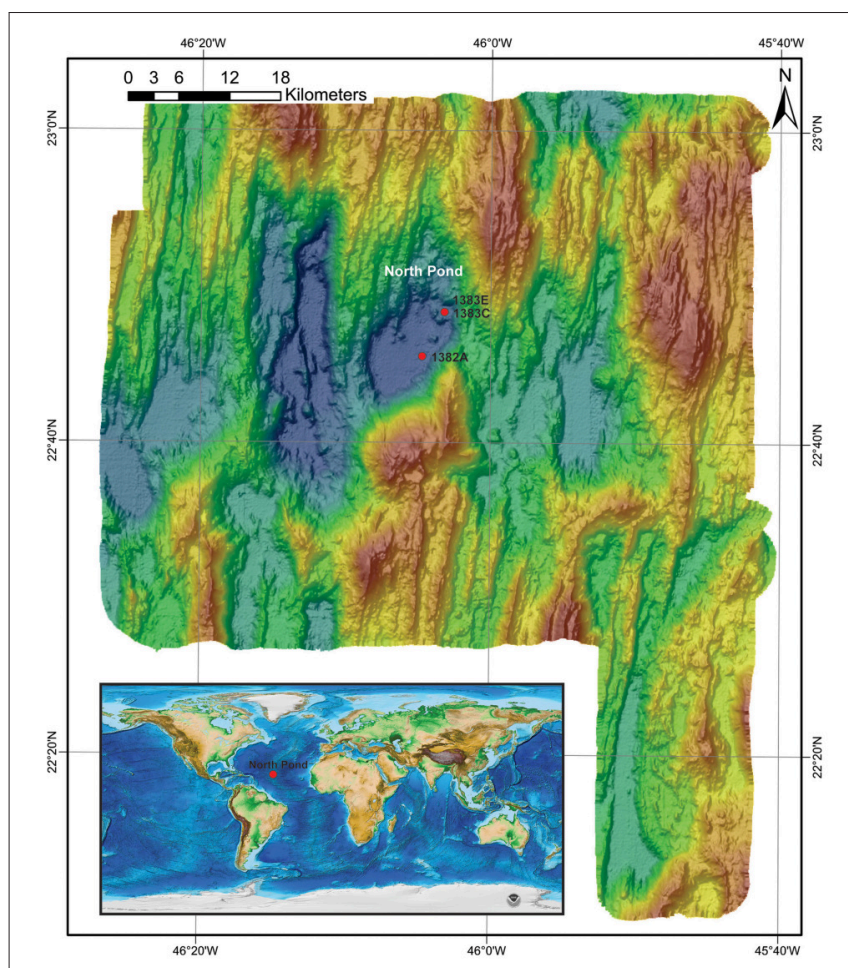

FIGURE 1 | Bathymetric map with the location of the investigated sites. Red circles indicate the geographic location of the investigated sites. Insert: global map indicating the position of North Pond in the Mid-Atlantic Ocean (Source: National Centers for environmental Information - NCEI). Modified from Bach (2012).

Hole (I, II, IV, V, VI, and VII). Unit V consist of sedimentary breccia; likely as a result of a rock slide deposit, whereas all other units are represented by basalt, either as varying volcanic pillow basalt or massive flows with geochemical and petrographic distinct characteristics. Rock alteration can be assigned to low temperature processes.

In Hole $1383 \mathrm{C}$ the sediment/basement interface was found at $38.3 \mathrm{mbsf}$ and 50.3 meter of hard rock was recovered from the interval between 69.5 and 331.5 mbsf (recovery 19\%). The 17 samples investigated from this Hole are glassy to fine-grained basalts with variable content of phenocrysts, which divides them into three major lithological units (I, II, and III).

\section{DNA Extraction}

Small pieces of sample material was pulverized in a flame sterilized steel mortar and $\sim 0.5 \mathrm{~g}(0.49-0.91 \mathrm{~g})$ from each sample was subjected to genomic DNA extraction using the FastPrep soil DNA isolation kit (MP Biomedicals) following the manufacturer's instruction with two modifications. First, we used a special bead coating, similar to the G2 DNA/RNA enhancer (Amplicon A/S, Odense, Denmark, available from June 2016) that increases yield, by reducing DNA binding to the beads (Baælum and Jacobsen, 2010; Bælum et al., 2013; Hjelmso et al., 2014). Next, $200 \mu \mathrm{g}$ of sterile filtered polyadenylic acid (PolyA; Sigma) was added to each lysis mixture prior to bead beating, to avoid DNA binding to the sample matrix (Hugenholtz et al., 1998). Bead beating was performed using the MP-Biomedical FastPrep ${ }^{\circledR}-24$ for $45 \mathrm{~s}$ (speed setting 6). DNA was finally eluted into $75 \mu \mathrm{l}$ PCR-grade double-distilled water $\left(\mathrm{ddH}_{2} \mathrm{O}\right)$, and preserved at $-80^{\circ} \mathrm{C}$ until further analysis. In order to assess potential contamination introduced from the extraction kit, two blank extractions were included using the same batch of chemical reagents as for the samples.

\section{Quantitative PCR}

Bacterial and Archaeal 16S rRNA genes were quantified individually using quantitative real time PCR applying the StepOne Real Time PCR system (Applied Biosystems). All samples and standards were run in triplicates using SYBR Green Hot Start master mixture (Qiagen) and with the standards, primers, and thermal conditions described in details elsewhere (Jørgensen et al., 2013). In short, a dilution series (10-10 6 target copies) containing Escherichia coli PCR amplified full-length 16S rRNA genes and a linearized archaeal fosmid (54d9) was used as bacterial and archaeal standards, respectively. Bacterial SSU rRNA genes were targeted with the primers bac341F (5'-CCTACGGGWGGCWGCA) and 518R (5'-ATTACCGCGGCTGCTGG). For archaeal SSU rRNA gene amplification the primers Un515F (5'-CAGCMGCCGCGGTAA) and Arc908R (5'-CCCGCCAATTCCTTTAAGTT) were used. All $R^{2}$ were $>0.95$ and the amplification efficiency between 90 and $104 \%$.

\section{Ion Torrent SSU rRNA Amplicon Library Preparation and Sequencing}

All DNA extracts were PCR amplified in duplicates with the SSU rRNA gene specific primers 519f (5'-CAGCMGCCGCGGTAA) and $805 \mathrm{r}$ (5'-GACTACHVGGGTATCTAATCC) in order to generate an amplicon library for subsequent sequencing using the Ion Torrent PGM Personal Genome Machine (PGM) platform technology (Life Technologies). We used a two-step amplification approach as described by Berry et al. (2011), to minimize bias introduced by the long adaptor sequence. The first-round PCR was carried out in duplicate for each sample, to minimize PCR drifting, and each reaction $(20 \mu \mathrm{l})$ contained $10 \mu 12 \mathrm{x}$ HotStarTaq ${ }^{\circledR}$ master mixture (Qiagen), $0.2 \mu$ l of each primer (100 $\mu \mathrm{M}$ stock), $2 \mu \mathrm{l}$ template and $\mathrm{ddH}_{2} \mathrm{O}$. The PCR program was initiated with a hot start activation step for 15 min at $95^{\circ} \mathrm{C}$ followed by an optimized number of PCR cycles (36-37) of $95^{\circ} \mathrm{C}$ for $30 \mathrm{~s}, 56^{\circ} \mathrm{C}$ for $30 \mathrm{~s}$, and $72^{\circ} \mathrm{C}$ for $30 \mathrm{~s}$. The duplicate PCR products were pooled and purified using QIAquick PCR purification kit (Qiagen). In the second-round PCR attaching the Multiplex Identifiers (MIDs), seven cycles were run, where each reaction $(25 \mu \mathrm{l})$ contained $12.5 \mu \mathrm{l} 2 \mathrm{x}$ HotStarTaq ${ }^{\circledR}$ master mixture (Qiagen), $0.2 \mu l$ 806r-B-Key (100 $\mu \mathrm{M}$ stock), and $2 \mu \mathrm{l} 519 \mathrm{f}$ MID primer (10 $\mu \mathrm{M}$ stock), with 5 $\mu l$ of purified PCR products from first-round amplification as the template, according to the Ion Torrent protocol. The PCR amplicons were purified using AMPure XP bead Purification Kit (Agencourt), following manufactures protocol, before all samples were pooled in equimolar concentrations (26 pmol). We note, that due to the PCR and the subsequent equimolar pooling, the 
TABLE 1 | General sample description including depth, lithological unit, onboard sample description, and in which group in the hierarchical cluster analysis the microbial community is located.

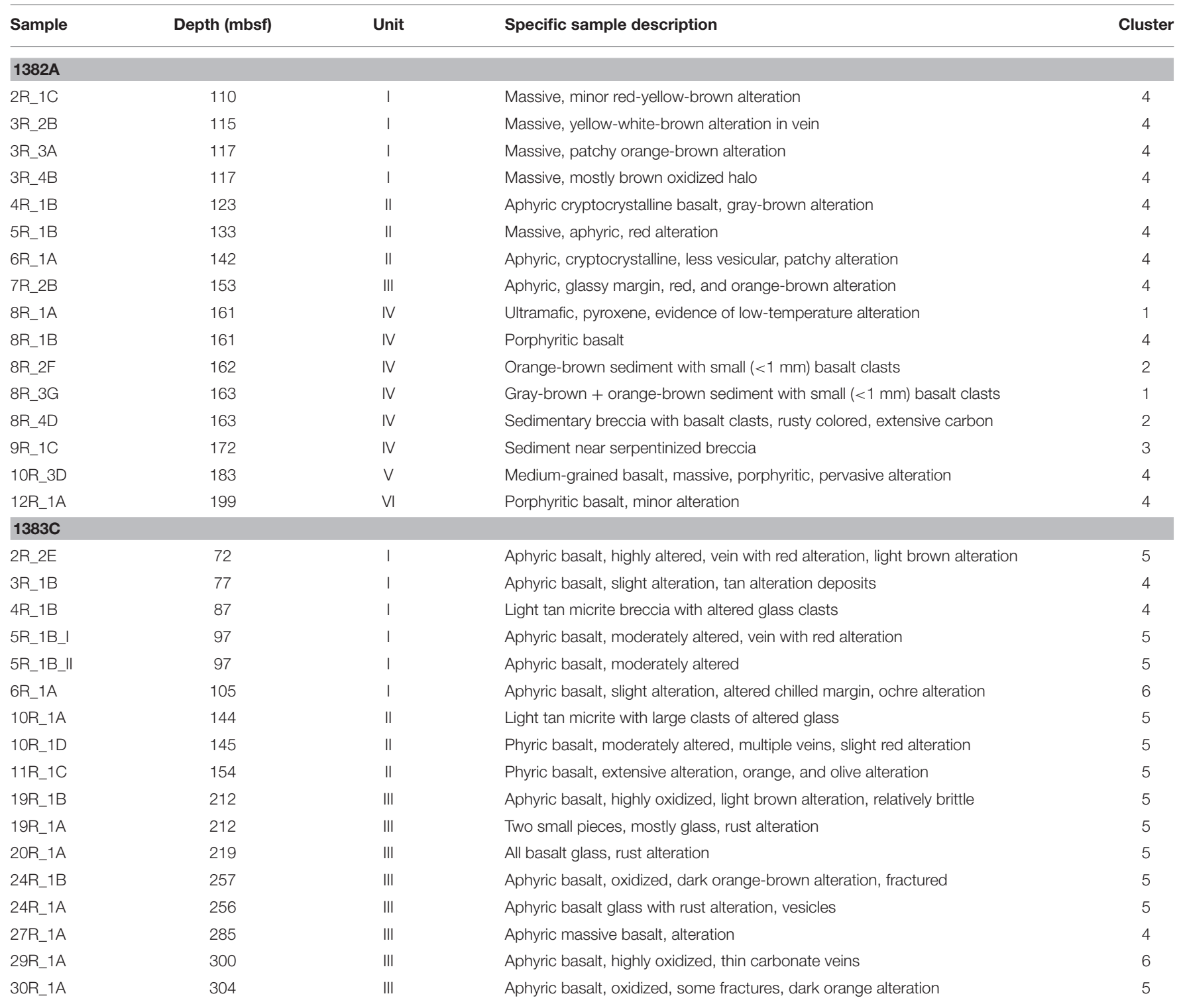

Cluster number corresponds to numbers in Figure 4. The sample description presented here is modified from IODP 336 site summaries (Expedition 336 Scientists, $2012 a, b)$.

number of reads do not reflect the original concentration of DNA, which based on gel band intensity after PCR was much higher in the samples than in the blank extractions. Raw reads generated in this study were deposited at the NCBI Sequence Read Archive under the project number SRP070121.

\section{OTU Filtering, Clustering, and Taxonomic Assignment}

Sequence reads obtained from the Ion Torrent sequencing were cropped at $220 \mathrm{bp}$ and quality filtered with a 0.5 quality cutoff, chimera checked, and Operational Taxonomic Units (OTUs) clustered (97\% similarity) using UPARSE/USEARCH (Edgar, 2013). The resulting OTUs were taxonomically assigned using the CREST software, with a lowest common ancestor algorithm implementing the SilvaMod reference database (Lanzen et al., 2012). A fasta sequence file of the represented OTUs can be found in the Supplementary Material (Data sheet S2).

\section{Contamination Assessment of Sequence Pool}

Contamination issues have previously hampered progress in deep marine research. In an attempt to avoid such obstacles this study applies several measures to prevent and assess the degree of potential contamination, as outlined in the sample handling and collection section above. Further, as a broad reaching contamination control for drilling protocols we extracted and 
sequenced DNA from the drill mud and a recovered microsphere bag (exposed to bottom seawater, drill fluid, and mud). The purpose of this control is to address potential inadvertent contamination of samples introduced during standard IODP drilling protocols. The results allow estimating the ratio of the inferred natural community that is likely to arise from contamination. Any OTU present in the control and in the native sample material was removed from the dataset. We note that true overlap between communities in the control and native samples may exist, which would lead to culling of legitimate sequences. Additionally, in order to assess potential contamination in the 16S rRNA gene amplicon preparation procedure two blank extractions (no sample material) were subjected to the same amplification protocol as the samples. Amplified DNA from these blanks may represent contamination originating from DNA extraction kit and/or PCR mix reagents (Champlot et al., 2010; Lusk, 2014; Salter et al., 2014). Therefore, any OTU found in both the extraction blanks and the native sample material was removed prior to any further downstream analysis, with the exception of OTUs that was found to be more than 50 times as abundant in the basalts than in the above-described controls. These were retained in the dataset, due to the plausible scenario of crosscontamination from controls to samples. This approach is similar to that described by Lee et al. (2015) with modified increased stringency addressing the assumed lower biomass in our sample set. However, in order to evaluate the impact of this stringent filtering, ordination, and clustering were likewise performed on the full dataset prior to the above described filtering.

\section{Ordination and Hierarchical Clustering Analysis}

The relative abundances of individual OTUs in each sample were clustered based on unconstrained Bray-Curtis, Jaccard, and Dice dissimilarity index using the software PAST version 3.08 (Hammer et al., 2001), before and after removal of potential contaminant reads. The basalt-hosted microbial communities were compared to those in the overlying sediments (Hole 1383E), using non-metric dimensional scaling (NMDS) applying Bray-Curtis dissimilarity. The data from the sediment samples was generated following identical protocols (e.g., the same primers, extraction kit, PCR mix), sequencing platform and downstream analysis, thereby enabling a valid comparison. The concentrations of major and trace elements from rocks provided by the IODP data report (Expedition 336 Scientists, 2012a,b) originating from the same core sections, but separated from the samples used for microbiology (between 20 and $70 \mathrm{~cm}$ distance), were used in cluster analysis using Bray-Curtis and Jaccard.

\section{RESULTS}

\section{S rRNA Gene Abundance}

The total abundance of $16 \mathrm{~S}$ rRNA gene copy numbers (Archaea plus Bacteria) estimated by qPCR varies between 0.3 and $8.3 \times$ $10^{4}$ copies per gram in Hole $1382 \mathrm{~A}$ and $0.6-3.9 \times 10^{4}$ copies per gram in 1383C (Table 2), with the majority of all samples $(80 \%)$ falling within the range of $1.9-5.8 \times 10^{4}$ copies. Three samples from the sedimentary breccia between 162.8 and 163.8 mbsf in Hole 1382A (8R-2F, 8R-3G, and 8R-4D) had notably lower numbers $\left(0.3-0.6 \times 10^{4}\right.$ copies per gram) than the remaining samples from this site. Based on our quantification the 16S rRNA genes are predominantly of bacterial origin, comprising between $92.6-100 \%$ and $91-100 \%$ in Hole $1382 \mathrm{~A}$ and $1383 \mathrm{C}$, respectively (Table 2). Assuming an average copy number per genome of 4.2 for Bacteria and 1 for Archaea (Stoddard et al., 2015), these copy numbers suggests cell abundances ranging $\sim 0.1-2 \times 10^{4}$ per gram of sample material (average $0.71 \times 10^{4}$ ).

\section{Sequence Reads, Filtering, and OTU Clustering}

The total number of sequence reads per sample after filtering and potential contaminants removal (OTUs present in the four controls) varied between 8598 and 25,841 with an average of 17,649 (Table 2). A total of 1,804 OTUs (>97\% sequence similarity) were found across all samples, of which 1,643 OTUs (91\% of total OTUs) were assigned to the bacterial domain, 44 OTUs (2.5\% of total OTUs) to the archaeal domain, while 60 OTUs (3.4\% of total OTUs) were Eukaryotic. The remaining 57 OTUs were classified as "no hits" which means that the sequence is $<80 \%$ similar to any in the database (Data sheet S1). The number of OTUs in the individual samples varied between 16 and 371 (Table 2). Blank extractions contained a combined total of 221 OTUs of which 142 were removed according to the criteria outlined in the Materials and Methods Section. An additional 50 OTUs were removed from the original data, as they were present in either the drill mud and/or on the recovered microsphere bag (12 and 46 OTUs, respectively).

\section{Microbial Community Composition}

As the microbial communities are spread across 41 different phyla, 73 classes, 155 orders, and 218 families, it is far beyond the scope of this work to address the community composition in all samples in detail. Therefore, only the results of the most abundant groups are listed here. However, a full list of OTUs present and their taxonomic assignments can be found in the Supplementary Material (Data sheet S1). In general the communities are relatively homogenous on higher taxonomic level across all samples, however in the sedimentary breccia the diversity of microorganisms and number of OTUs are extraordinarily low, especially in the middle section of that lithological unit (Figure 2 and Table 2), in many ways causing these samples to deviate substantially from the rest.

All samples are dominated by Proteobacteria (35-99\% of the total communities) of which the class of Gammaproteobacteria is the most abundant, followed by Alphaproteobacteria, Deltaproteobacteria, and Betaproteobacteria, respectively (Figure 2A and Data sheet S1). Only very low abundances, if any, were assigned to the class of Epsilonproteobacteria and Zetaproteobacteria. Analysing the different classes of Proteobacteria with higher taxonomic resolution show that many (average 60\%) of the Gammaproteobacteria could not be assigned below class level (Figure 2B). The majority of these were represented by OTU5, which showed high similarity (100\%) to Pseudomonas when performing NCBI blast search. The limited taxonomic resolution of OTU5 in our analysis is 
TABLE 2 | General molecular characteristic of the samples investigated.

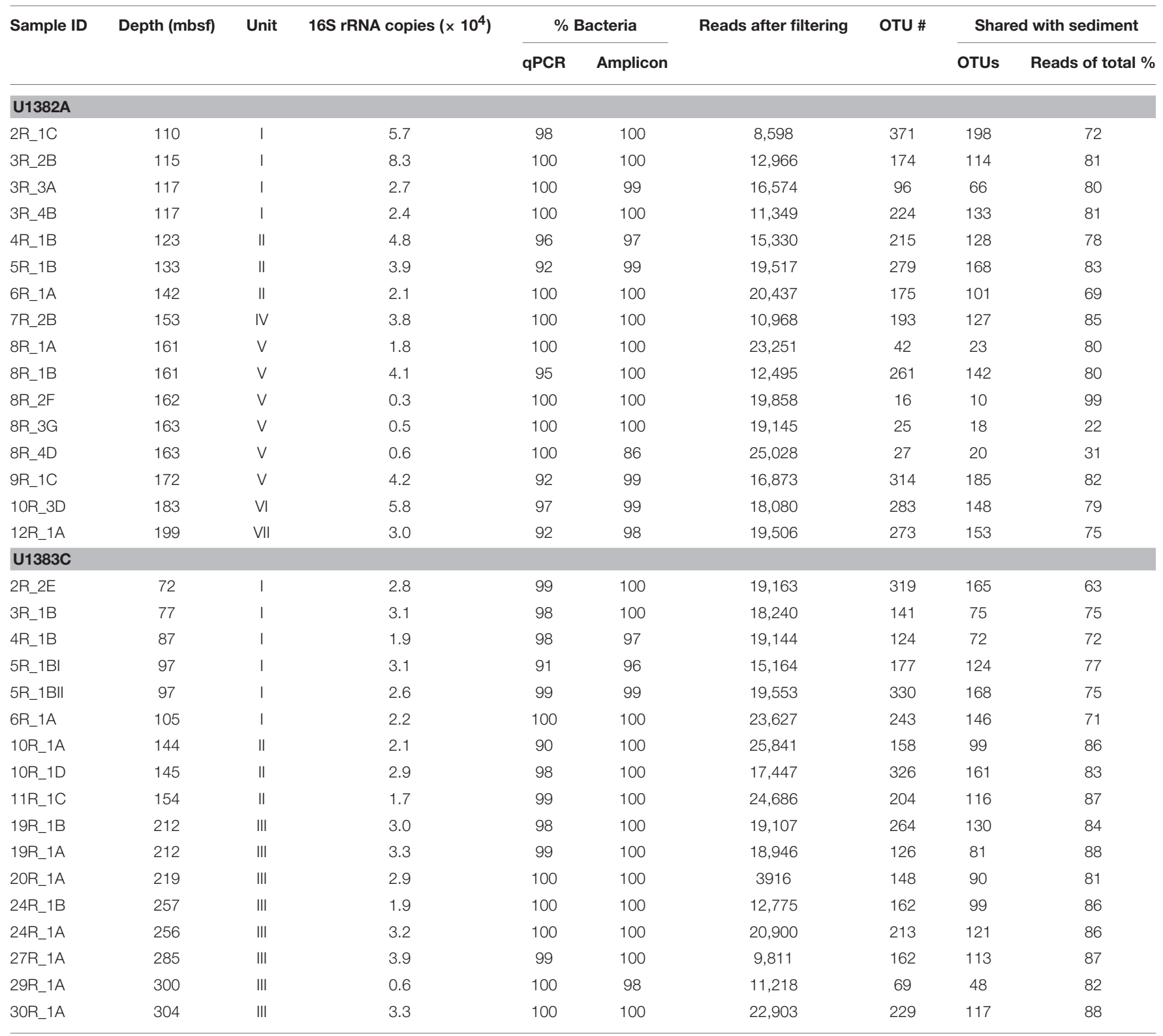

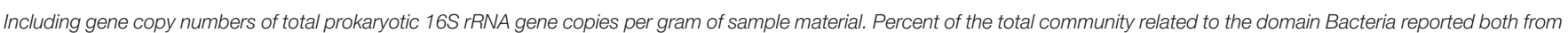

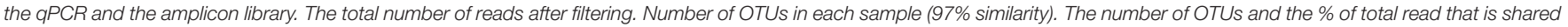
with the samples in the above sediment from North Pond (1383E).

likely due to the high stringency used by the lowest common ancestor algorithm applied to assign taxonomy. Most of the reminding Gammaproteobacteria in Hole 1382A belonged to the two orders Oceanospirillales, mainly affiliated with the SAR86 clade and Pseudmonadales, (largely divided between the families Moraxellaceae and Pseudomonadaceae). In contrast, the most abundant Gammaproteobacterial order from Hole 1383C is Alteromonadales, whereof most can only be assigned to family level (Alteromonadaceae) and to a lesser extent Marinobacter $(<1 \%$ of total community). Although, abundance-variation between samples is present within the Alphaproteobacteria, as for all taxonomic groups, Rhizobiales, Rhodobaceriales, and Rhodospirilialles were in general the most abundant orders (Figure 2C). At both sites, Burkholderiales was by far the most prominent member of the Betaproteobacteria at the order level, with the genus Variovorax accounting for approximately half of this group and the family Oxalobacteraceae representing the other half (Figure 2D and Data sheet S1). The overall abundance of Deltaproteobacteria was relatively low and in Hole 1382A it was dominated primarily by Myxococcales and the SAR324 clade whereas Bdellovibrionales and Desulfobacterales were the most abundant orders in Hole 1383C (Figure 2E). In addition 
to the mentioned members of the Proteobacteria the following phyla were found in relatively high abundances; Actinobacteria, Firmicutes, Bacteroidetes, and Acidobacteria along with a number of less abundant groups, but still representing more than $1 \%$ of all reads in one or more samples, such as Planctomycetes and Chloroflexi (see Figure 2A).

The archaeal community constitute only a minor fraction of the entire community (max. 5\%, avg. $0.6 \%$ of all reads) and is represented by five phyla; Ancient Archaeal Group (AAG), Crenarchaeota, Euryarchaeota, Thaumarchaeota, and the newly proposed Lokiarchaeota (Spang et al., 2015; Figure 2A and Data sheet S1). Of these, Thaumarchaeal Marine Group I is by far the most abundant.

A comparison between the rank abundance of the 576 OTUs shared between the basalt and the overlying sediment was performed using the average abundances of the OTUs across all basalt and across all sediment samples, excluding the sedimentary breccia from Hole 1384A (Figure 5). The shared OTUs represented between 63 and $86 \%$ (average $80 \%$ ) of all reads in the basalt and $44-71 \%$ (average 58\%) in the sediments, but show a markedly different rank abundance distribution (Table 2 and Figure 5).

\section{Ordination and Clustering Analysis}

The variation in the microbial community structure (relative abundance of OTUs) found in the basaltic samples beneath North Pond was compared to the composition in a number of sedimentary horizons in Hole 1383E directly overlying the basaltic crust by means of NMDS. The sedimentary community was investigated at 17 different depths, spanning from the top of the sediment to a few meters above the sediment basement interface and clearly shows a separation from those observed in the underlying upper crust (Figure 3). The microbial composition in the sedimentary breccia (lithological unit $\mathrm{V}$ ) in Hole 1382A are markedly different from the rest of the samples from this sites and also from the basaltic rocks from Hole 1383C, causing these samples to cluster alone, with the exception of sample 8R_1B (the only basalt sample within the breccia unit). An NMDS analysis was also carried out on the full dataset, before removal of any of the OTUs found in the four controls, as described in the Materials and Methods Section. This result shows the same pattern, as with the "cleaned" dataset presented in Figure 3, and verifies that all control samples are markedly different from any of the indigenous samples (Figure S1).

In order to investigate any link between community composition and lithology a hierarchical clustering analysis based on the relative abundance of OTUs was executed. The results show several minor (group 1, 2, 3, 6) and two major (group 4 and 5) clusters separated by high bootstrap value (Figure 4). The major clusters largely distinguish the two sites from one another. However, three samples from Hole $1383 \mathrm{C}$ cluster within 1382A. The bootstrap values are generally low and clustering according to lithology or depth cannot be inferred. The clustering using the full dataset, before removal of potential contaminant reads in general shows the same clustering pattern, however a higher degree of mixing between the two sites is observed (Figure S2). The results from clustering based on Jaccard and Dice dissimilarity indexes, showed no clear difference in clustering pattern as compared to Bray-Curtis (data not shown). Using the geochemical data (major and trace elements) from the same core sections as those used for microbiology, in a hierarchical clustering, shows only very small variation in composition. No clear clustering pattern between sites or lithology could be observed and most branching points were unsupported (Figure S3).

\section{Contamination Control}

The presence of fluorescent microspheres in the sterile seawater used to wash the basalt rock surface was investigated on board the ship. After three washing rounds, microspheres were detected in $36 \%$ of the samples (Figure 4) and more frequently observed in Hole 1383 C than 1382A.

Drill mud and the microsphere bag yielded a total of $\sim 47,500$ high-quality reads comprising a number of different bacterial taxa (Data sheet S1). After removal of extraction blanks, 12 OTUs were obtained from the drill mud and 46 from the microsphere bag, most of these were affiliated with Streptococcus, a group that are often associated with human pathogens. A larger number of OTUs were obtained from the microsphere plastic bag, many of which were affiliated with different SAR clades. However, also here a number of reads were associated with bacterial groups often associated with humans (e.g., Streptococcus and Dermabacter; Data sheet S1). Standard drilling protocols inevitably introduce contaminants to drilling components and we propose this as an explanation for the detection of human associated taxa.

Extraction blanks were represented by $\sim 16,000$ reads whereof the vast majority could be assigned to the following three taxonomic groups: Ralstonia, Enterobacteriaceae, and Methylobacterium. On average 38\% of all reads were removed during the cleaning procedure (total of 158 OTUs) highlighting the importance of performing operation controls and analysing blank extractions, especially when working with low biomass sample material (Data sheet S1).

\section{DISCUSSION}

\section{Microbial Abundances in Subsurface Basaltic Crust}

Based on our qPCR results of prokaryotic 16S rRNA gene abundances, we estimate that the samples contain $\sim 10^{4}$ cells per gram of rock sample, with Bacteria outnumbering Archaea in all samples (Table 2). However, as with all cell estimates based on a primer-based approach it is prone to bias and the numbers should be evaluated with this in mind. It is difficult to compare our estimates with earlier reports since, to the best of our knowledge, only one previous study has been conducted in which direct cell abundances were estimated from native cold subsurface basalt (Fisk et al., 2003). Based on amino acid concentration they suggest $\sim 10^{5}$ cells per gram sample. A recent study estimated cell numbers in the basaltic fluids from both investigated sites, to be between 1.4 and $2.2 \times 10^{4}$ per ml fluid, based on direct cell counts (Meyer et al., 2016). Considering the average basaltic porosity of $4 \%$ and assuming a density of 3 , implies that our quantification 
A

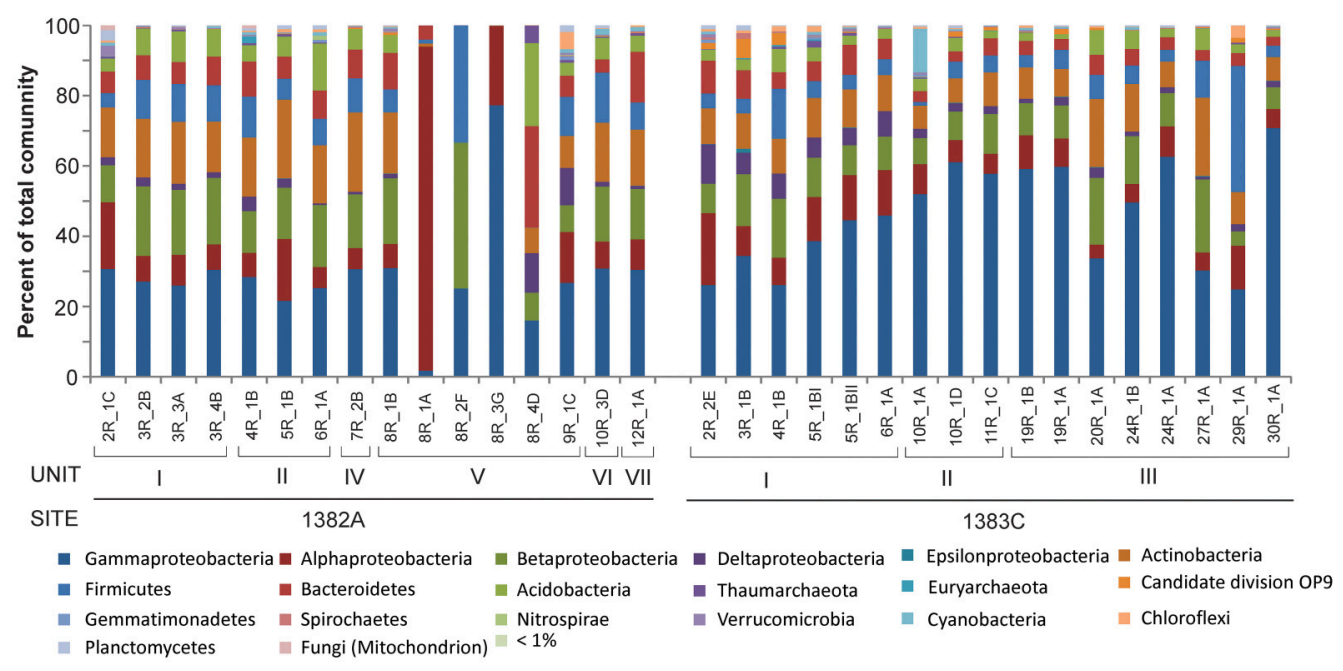

B

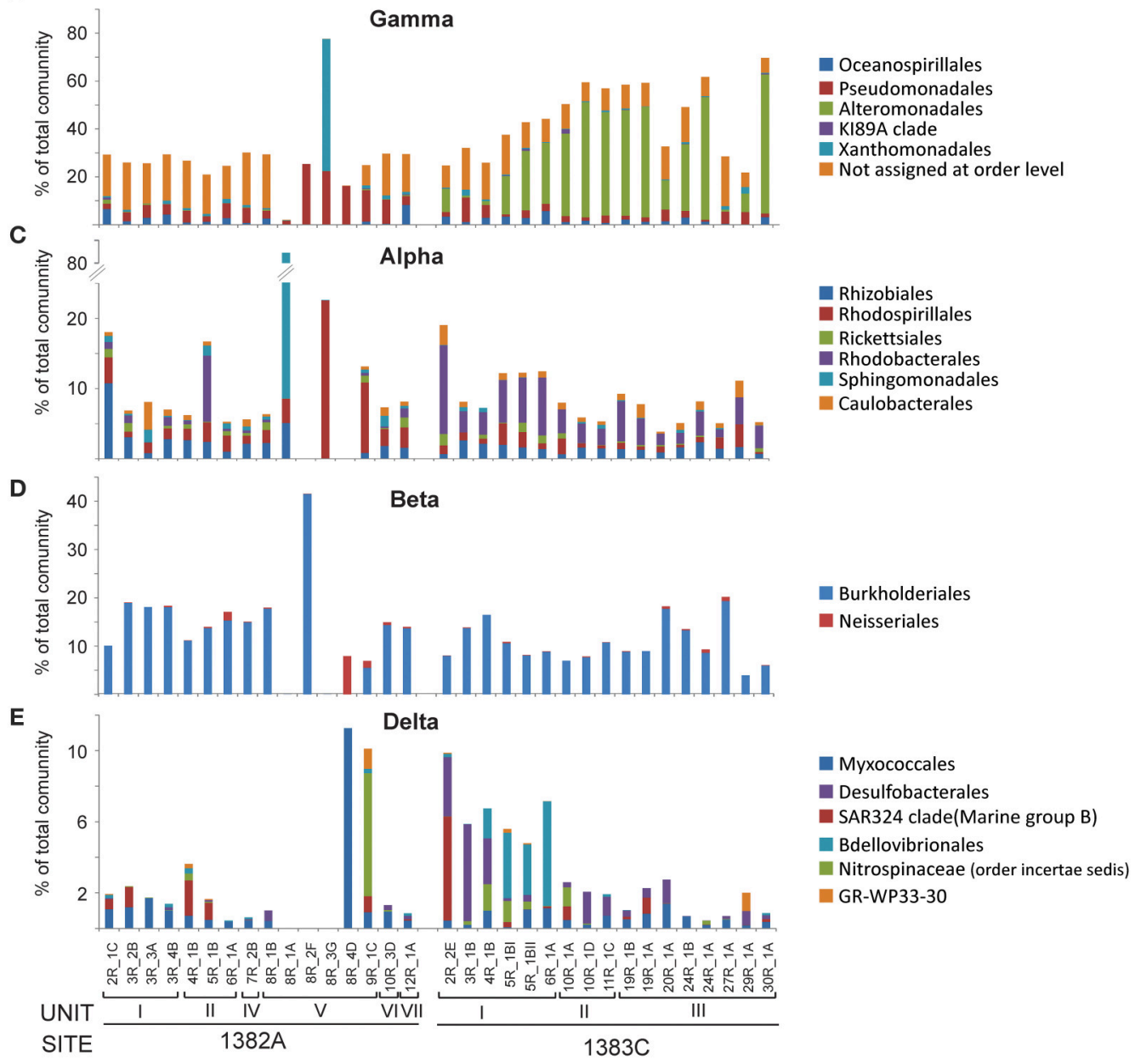

FIGURE 2 | Relative abundance of taxonomic groups. (A) Class level abundances of Proteobacteria and phylum level for all other groups comprising more than $1 \%$ of total community in one or more samples. Abundances for the taxonomic orders representing more than $1 \%$ of total community of (B) Gammaproteobacteria, (C) Alphaproteobacteria, (D) Betaproteobacteria, and (E) Deltaproteobacteria. 


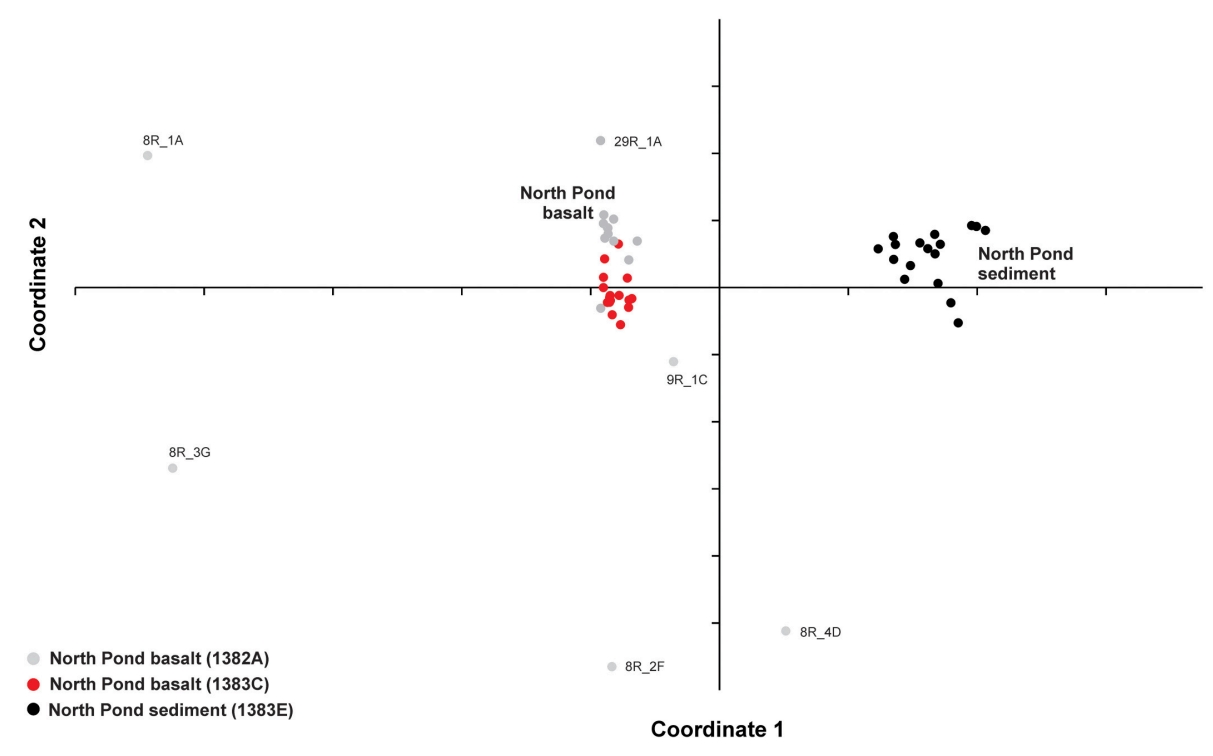

FIGURE 3 | Comparison between community structures. Relative abundance of OTUs in each sample was used to compare the variation between the basalt-hosted communities and the sediment-hosted communities by means of non-metric multidimensional scaling (NMDS). Samples are color coded gray: Hole 1382A, red: 1383C, black: North Pond sediment from Hole 1383E.

is not merely representing cells in the fluid, but that the majority must be attached to the rock surfaces.

Due to the restricted number of sites in our study we have restrained ourselves from the tantalizing prospect of extrapolating the cell abundance to global biomass. However, we note that a previous estimate based on thermodynamic and bioenergetic models was suggested to translate into $\sim 10^{7}-10^{9}$ cells per gram rock (Santelli et al., 2008). In other words, 3-5 orders of magnitudes off our estimations. In support of a lower cell abundance is the relatively low oxygen consumption $(<1$ nmol $\mathrm{O}_{2} \mathrm{~cm}^{-3}$ rock $\mathrm{d}^{-1}$ ) estimated beneath North Pond (Orcutt et al., 2013). Another interesting observation related to the cell numbers is the relative consistency across all samples, which suggest that the cells are limited by a common vital anabolic or catabolic resource.

\section{Microbial Community Composition in Subsurface Basaltic Crust}

Based on the 16S rRNA amplicon libraries the microbial communities in the subsurface basalt in North Pond are all dominated by Bacteria, in general leaving the archaeal domain represented by $<1 \%$. Although, our qPCR estimations vary slightly from this, both analyses confirm the bacterial dominance (Table 2). By far the most abundant phylum was Proteobacteria, with Gamma-, Beta-, and Alphaproteobacteria constituting the majority within this phylum. In addition Actinobacteria, Firmicutes, Bacteroidetes, and Acidobacteria were all represented by relatively high abundances. To the best of our knowledge, only one previous published study has successfully amplified DNA from native subsurface material and determined the community composition (Lysnes et al., 2004).
By means of DGGE that study reported sequences related to Gammaproteobacteria, Actinobacteria, Bacteroidetes, Chloroflexi, and Firmicutes, of which Gammaproteobacteria was the most abundant. A more recent study compiled taxonomic data from a number of studies regarding surface-exposed basalts and identified a set of commonly found abundant microbial groups, including Gamma-, Alpha-, and Deltaproteobacteria, as well as Actinobacteria, Bacteroidetes, Acidobacteria, Planctomycetes, Gemmatimonadetes, and Nitrospirae (Lee et al., 2015). Finally, the microbial community composition in the fluids underneath North Pond has revealed a similar dominance of Proteobacteria, also with Gammaproteobacteria being most abundant, then followed by Alpha-, Epsilon-, Beta-, and Deltaproteobacteria (Meyer et al., 2016). Further, relative high abundances of Actinobacteria, Bacteroidetes, planctomycetes, Gemmatimonadetes, and Chloroflexi were observed. Based on this it is tempting to suggest that a basalt-hosted taxonomic core group exists, including surface, subsurface fluids, and hard rocks. However, it is important to stress that the similarity of microbial groups in all cases is based on high taxonomic rank and future in-depth phylogenetic comparison, founded on full-length 16S rRNA sequences, are needed to resolve this issue.

The origin of the subsurface oceanic crustal community is an open question and different scenarios have been debated, one of them being that dispersion may occur via the above sediment column (Huber et al., 2006; Schrenk et al., 2010). When we compared the relative community composition in the basaltic rocks with that in overlying sediment striking differences were observed (Figure 3). However, this is by no means indicative of community isolation between the crust and sediment. On the contrary, a high degree of overlap was revealed from the OTUs distribution pattern. Of the 1,802 OTUs 


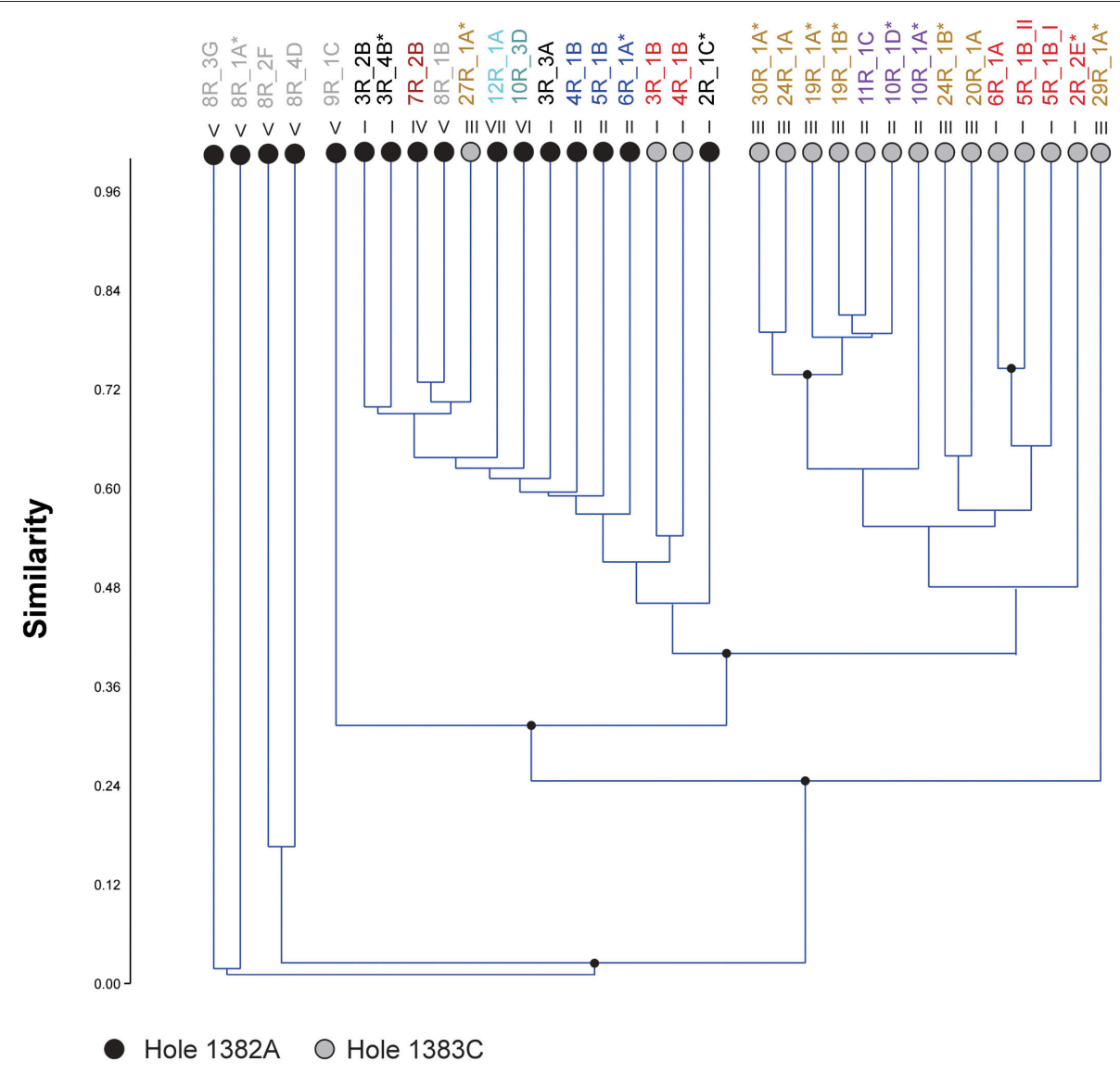

FIGURE 4 | Microbial community clustering. Relative abundance of OTUs in each sample was used to cluster the different communities within the crustal samples from North Pond by means of Bray-Curtis distance calculations. Circles at the end of each branch indicates sampling site; gray: Hole 1383C, black; Hole 1382A. Roman numerals above the branches indicate the lithological unit, also indicated by colors in the sample name above. Asterisk indicates presence of microspheres in the wash fluids after last washing. Numbers above sample name indicates clusters supported by high bootstrap values (> 90) and are identical to numbers used in Table 2.

found across all 33 crustal samples, 576 OTUs were shared with the sedimentary habitat above, comprising as much as $63-86 \%$ (average $80 \%$ ) of all reads in the basaltic samples. However, the relative distributions of the shared OTUs in the two environments are markedly different, which might reflect environment-specific taxon recruitment based on availability of electron donors and acceptors (Figure 5). Based on these results the two components of the deep biosphere do indeed share many of their microbial inhabitants. Although, the dynamics and mechanisms of taxon dispersal between the crustal and sedimentary subseafloor regimes is beyond the scope of this study, we note that a recent study support the dispersal of sedimentary bacteria via the ocean (Walsh et al., 2016).

Regarding the heterogeneity of crust-associated microbial communities beneath North Pond, we note that although the communities from the two different sites to a large degree cluster together, (Figure 3), there are also clear differences (Figure 4). Two major clusters, supported by high bootstrap values $(>90)$ were found, largely separating the two investigated sites from one another. Notable differences are the presence of a few highly abundant OTUs affiliating with an uncultured Alteromonas lineage (Gammaproteobacteria) in Hole $1383 \mathrm{C}$ and a much higher occurrence of Rhodobacterales (Betaproteobacteria) in Hole $1383 \mathrm{C}$ than in Hole 1382A. The significance of this is not known, but it is possible that the physico-chemical nature, and associated redox coupling, of advective crustal fluids, drive community differentiation.

\section{Potential Metabolic Traits and Dominant Groups}

The vast majority of lineages reported here do not group within taxonomic clades with known metabolism, and therefore their potential role in the ecosystem is unresolved. However, a number of less abundant groups with relatively constrained metabolic potential are present, thereby allowing us to assign their function with some degree of certainty. For example, as putative sulfate reducers in other environments a number of different genera were observed, including, Desulfotomaculum, Desulfurispora, Desulfosporosinus, Desulfobaca, Desulfobulbus, Desulforomonas, Desulfovibrio, and Desulfobacula, suggesting that at least the potential for active sulfate reduction is present. The classical sulfur oxidizers (mainly within Epsilonproteobacteria), on the 


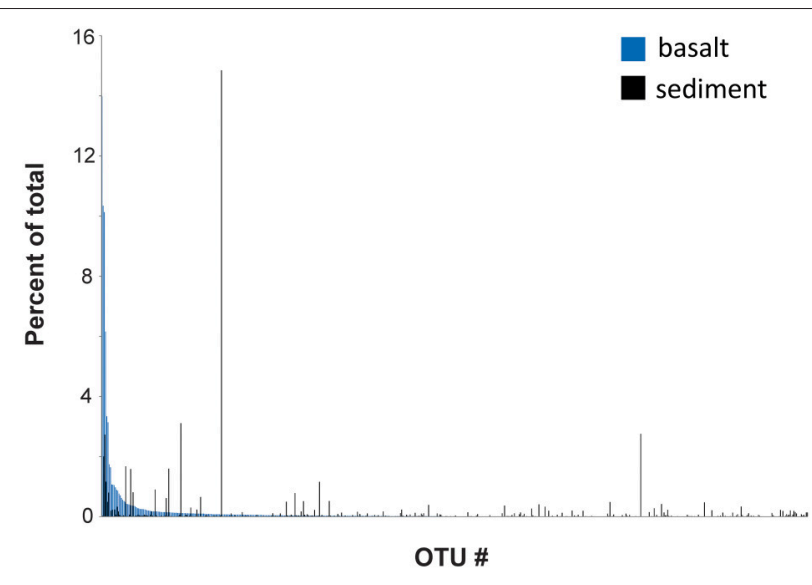

FIGURE 5 | OTU rank abundance. Comparing the rank abundance of OTUs shared between the basalt-hosted community (Holes 1382A and 1383C) and the sediment-hosted (1383E). The abundance of each OTU across all

basalt-hosted samples and across all sediment samples was compiled and the average abundance used (excluding the sedimentary breccia in Hole 1382A).

other hand, were only sporadically observed. This observation is worth mentioning in the context of the relatively high abundances of sulfur oxidizers found in the fluids by Meyer et al. (2016) and in the overlying sediments, suggesting different functions between the free-living and the surface-attached communities.

Iron and hydrogen (beside sulfur) has been proposed to be important electron donors in this type of habitat (Bach and Edwards, 2003; Edwards et al., 2005). However, known metal reducers such as, Marinobacter, Shewanella, Geobacter, and Ferruginibacter made up only a minor fraction of the entire community (Marinobacter up to 0.3\%). Hydrogen utilization is another widespread trait that is difficult to pinpoint based on taxonomy alone, hence we could only assign this to Hydrogenophilus, Hydrogenophaga, and Paracoccus, all represented in the dataset, but in low abundances.

Finally, we observe a number of groups with the ability to transform nitrogen compounds. This includes members of the putative ammonium-oxidizing archaeal Marine Group I ( $<5 \%$ of total community) and nitrifiers (Nitrospira), which was detected in discrete samples up to $0.5 \%$. Despite, the relative low abundances, their presence suggest an active nitrogen cycle, which is in congruence with the low concentration of organic carbon measured in this environment (Orcutt et al., 2015; Sakata et al., 2015).

\section{Contamination Control}

A great concern related to investigations of subsurface crustal material (and the deeply buried biosphere in general) has been the challenge of overcoming issues related to contamination constrains (Lever et al., 2006; Santelli et al., 2010). In order to delineate potential sources of contamination (acquired during drilling or subsequent sample processing) we analyzed two sample processing controls (extraction blanks) and two drilling operation controls (drill mud and a recovered empty microsphere bag). Designation of potential contaminants facilitates the tracking of their source in addition to their downstream removal from the bioinformatic pipeline as described before. As more reads were removed from the native samples due to their overlap with extraction blanks rather than with the drill mud and microsphere bag, we conclude that more contamination was introduced during DNA extraction and amplification than from the actual drilling procedure. However, we acknowledge that contamination could have originated from drilling or downstream procedures not accounted for by our contamination controls.

Despite, the observed contamination, several lines of evidence suggest that the final community structure is not corrupted: (i) the bifurcation of community structure of the two crustal sites, (ii) drastic differences between the composition and structure of sedimentary and crustal samples, despite equally low biomass, (iii) congruence between our results and taxonomic identity of enriched organisms from independent studies at this site, including Pseudomonas, Burkholderia, Bacillus, Salinibacterium, Sphingomonas, Moraxella, and Methylobacterium (Hirayama et al., 2015), (iv) agreement with core-taxa hitherto identified in basalt hosted environments (Lysnes et al., 2004; Lee et al., 2015) and in the fluids under North Pond (Meyer et al., 2016).

In sum, the data shows that contamination in low abundance habitats is a concern, and we encourage that both extraction and operation controls are performed. If such measures are taken the influence of contamination in data analysis seems manageable.

We also note that the presence of microspheres, a general measure of contamination deployed during IODP drilling operations, does not seem to be reflected in the magnitude of contamination in the 16S rRNA gene libraries (measured as number of reads removed in the filtering due to drill mud contamination).

\section{CONCLUSIONS}

Our study gives some of the first insights into the microbial inventory of the subsurface oceanic crust in a young cool ridge flank system and show a community dominated by Proteobacteria (Gammaproteobacteria, Alphaproteobacteria, and Betaproteobacteria), followed by Actinobacteria, Firmicutes, Bacteroidetes, and Acidobacteria. In general, the same phyla are present in high abundances on seafloor-exposed basalts and in the crustal fluids, suggesting the possibility for a common basalt-hosted microbial biome. However, more data is needed to establish if a core group also exist at deeper taxonomic levels. Within the crustal communities we find microbial representatives that are likely to be involved in iron, sulfur, hydrogen, and nitrogen cycling but all in relative low abundances. However, the activity levels might be considerably higher than what the relative abundance implies.

Our estimated cell abundances are on average $0.7 \times 10^{4}$ cells per gram of igneous rock, several orders of magnitude lower than what has been found on seafloor-exposed basalt (e.g., Einen et al., 2008; Santelli et al., 2008). The abundance is relatively consistent across all samples and we therefor speculate that the available 
energy is equal across the different samples and/or cell numbers are limited by a common nutrient factor.

Further, the variations in community structure between the samples do, to a large extent, separate the two investigated sites (1382A and 1383C) into two major clusters with no apparent link to differences in lithology. Comparing the basalthosted community structure to the overlying sediment using the relative distribution of individual OTUs clearly separates the two environments. However, $\sim 1 / 3$ of all OTUs in the basalt, representing an average of $80 \%$ of all sequences, were also present in the overlying sediment, indicating coupling between the two compartments of the deep biosphere. This observation is interesting with respect to the origin of the microorganisms inhabiting the crustal aquifer, however, deciphering the direction of cell dispersal, the source and the nature and underlying mechanisms of such links needs further investigation.

\section{AUTHOR CONTRIBUTIONS}

SJ designed the research; SJ and RZ performed the research; SJ and RZ analyzed the data; and SJ and RZ wrote the manuscript.

\section{REFERENCES}

Baælum, J., and Jacobsen, C. S. (2010). Pre-treating DNA/RNA Adsorbing Matrix Sample for Extracting Cell-derived Target DNA/RNA, by Isolating Sample of DNA/RNA Adsorbing Matrix and Contacting Sample with DNA of Natural Origin in Fragmented Form. Patent No. WO2010146026-A1, US2012094353A1, EP2443251-A1.

Bach, W. (2012). Borehole Microbial Observatory Science in Basaltic Ocean Crust: The North Pond Area on the Western Mid-Atlantic Ridge Flank at $23^{\circ} \mathrm{N}$. Cruise Report MSM20/5, DFG Senatskommission für Ozeanographie, Freeport. doi: 10.2312/cr_msm20_5

Bach, W., and Edwards, K. J. (2003). Iron and sulfide oxidation within the basaltic ocean crust: implications for chemolithoautotrophic microbial biomass production. Geochim. Cosmochim. Acta 67, 3871-3887. doi: 10.1016/S00167037(03)00304-1

Bach, W., Garrido, C. J., Paulick, H., Harvey, J., and Rosner, M. (2004). Seawaterperidotite interactions: First insights from ODP Leg 209, MAR 15 degrees N. Geochem. Geophys. Geosys. 5:Q09F26. doi: 10.1029/2004gc000744

Bælum, J., Chambon, J. C., Scheutz, C., Binning, P. J., Laier, T., Bjerg, P. L., et al. (2013). A conceptual model linking functional gene expression and reductive dechlorination rates of chlorinated ethenes in clay rich groundwater sediment. Water Res. 47, 2467-2478. doi: 10.1016/j.watres.2013.02.016

Berry, D., Ben Mahfoudh, K., Wagner, M., and Loy, A. (2011). Barcoded primers used in multiplex amplicon pyrosequencing bias amplification. Appl. Environ. Microbiol. 77, 7846-7849. doi: 10.1128/AEM.05220-11

Champlot, S., Berthelot, C., Pruvost, M., Bennett, E. A., Grange, T., and Geigl, E.-M. (2010). An efficient multistrategy DNA decontamination procedure of PCR reagents for hypersensitive PCR applications. PloS ONE 5:e13042. doi: 10.1371/journal.pone.0013042

Edgar, R. C. (2013). UPARSE: highly accurate OTU sequences from microbial amplicon reads. Nat. methods 10, 996-998. doi: 10.1038/nmeth.2604

Edwards, K. J., Bach, W., and McCollom, T. M. (2005). Geomicrobiology in oceanography: microbe-mineral interactions at and below the seafloor. Trends Microbiol. 13, 449-456. doi: 10.1016/j.tim.2005.07.005

Edwards, K. J., Becker, K., and Colwell, F. (2012b). The deep, dark energy biosphere: intraterrestrial life on earth. Annu. Rev. Earth Planet. Sci. 40, 551-568. doi: 10.1146/annurev-earth-042711-105500

\section{ACKNOWLEDGMENTS}

This article is dedicated to the late Katrina Edwards. We thank the entire scientific party, especially the basaltic sampling crew and all crewmembers onboard Joides Resolution during IODP expedition 336, for their help and expertise. Co-chief scientists Katrina Edwards and Wolfgang Bach were instrumental in realizing this great undertaking, and are gratefully acknowledged. We thank Håkon Dahle for helping to develop the bioinformatic pipeline. The comments and suggestions from Gustavo Ramirez on the final version of this article are much appreciated. This study used samples and data provided by the IODP and was funded by the Norwegian Research Council through the Centre for Geobiology, University of Bergen.

\section{SUPPLEMENTARY MATERIAL}

The Supplementary Material for this article can be found online at: http://journal.frontiersin.org/article/10.3389/fmicb. 2016.00820
Edwards, K. J., Fisher, A. T., and Wheat, C. G. (2012a). The deep subsurface biosphere in igneous ocean crust: frontier habitats for microbiological exploration. Front. Microbiol. 3:8. doi: 10.3389/fmicb.2012.00008

Einen, J., Thorseth, I. H., and Ovreas, L. (2008). Enumeration of Archaea and Bacteria in seafloor basalt using real-time quantitative PCR and fluorescence microscopy. FEMS Microbiol. Lett. 282, 182-187. doi: 10.1111/j.15746968.2008.01119.x

Expedition 336 Scientists (2012a). "Site U1382," in Proc IODP, 336, eds K. J. Edwards, W. Bach, A. Klaus, and The Expedition 336 Scientists (Tokyo: Integrated Ocean Drilling Program Management International, Inc.).

Expedition 336 Scientists (2012b). "Site U1383," in Proc IODP, 336, eds K. J. Edwards, W. Bach, A. Klaus, and The Expedition 336 Scientists (Tokyo: Integrated Ocean Drilling Program Management International, Inc.).

Expedition 336 Scientists (2012c). "Methods," in Proc IODP, 336, eds K. J. Edwards, W. Bach, A. Klaus, and The Expedition 336 Scientists (Tokyo: Integrated Ocean Drilling Program Management International, Inc.).

Expedition 336 Scientists (2012d). "Sediment and basement contact coring," in Proc IODP, 336, eds K. J. Edwards, W. Bach, A. Klaus, and The Expedition 336 Scientists (Tokyo: Integrated Ocean Drilling Program Management International, Inc.).

Expedition 336 Scientists (2012e). "Expedition 336 summary", in Proc IODP, 336, eds K. J. Edwards, W. Bach, A. Klaus, and The Expedition 336 Scientists (Tokyo: Integrated Ocean Drilling Program Management International, Inc.).

Fisher, A. T., and Becker, K. (2000). Channelized fluid flow in oceanic crust reconciles heat-flow and permeability data. Nature 403, 71-74. doi: $10.1038 / 47463$

Fisk, M. R., Giovannoni, S. J., and Thorseth, I. H. (1998). Alteration of oceanic volcanic glass: textural evidence of microbial activity. Science 281, 978-980. doi: $10.1126 /$ science. 281.5379 .978

Fisk, M. R., Storrie-Lombardi, M. C., Douglas, S., Popa, R., McDonald, G., and Di Meo-Savoie, C. (2003). Evidence of biological activity in Hawaiian subsurface basalts. Geochem. Geophys. Geosyst. 4:1103. doi: 10.1029/2002gc 000387

Furnes, H., Muehlenbachs, K., Torsvik, T., Thorseth, I. H., and Tumyr, O. (2001a). Microbial fractionation of carbon isotopes in altered basaltic glass from the Atlantic Ocean, Lau Basin and Costa Rica Rift. Chem. Geol. 173, 313-330. doi: 10.1016/S0009-2541(00)00285-0 
Furnes, H., Staudigel, H., Thorseth, I. H., Torsvik, T., Muehlenbachs, K., and Tumyr, O. (2001b). Bioalteration of basaltic glass in the oceanic crust. Geochem. Geophy. Geosy. 2:1049. doi: 10.1029/2000gc000150

Giovannoni, S., Fisk, M., Mullins, T., and Furnes, H. (1996). Genetic evidence for endolithic microbial life colonizing basaltic glass/sea water interfaces. Ocean Drill. Prog. 148, 207-214. doi: 10.2973/odp.proc.sr.148.151.1996

Hammer, Ø., Harper, D., and Ryan, P. (2001). PAST: Paleontological statistics software package for education and data analysis. Palaeontol. Electron. 4, 9. Available online at: http://palaeo-electronica.org/2001_1/past/issue1_01.htm

Heberling, C., Lowell, R. P., Liu, L., and Fisk, M. R. (2010). Extent of the microbial biosphere in the oceanic crust. Geochem. Geophys. Geosyst. 11:Q08003. doi: $10.1029 / 2009 \mathrm{gc002968}$

Hirayama, H., Abe, M., Miyazaki, J., Sakai, S., Nagano, Y., and Takai, K. (2015). "Data report: cultivation of microorganisms from basaltic rock and sediment cores from the North Pond on the western flank of the Mid-Atlantic Ridge, IODP Expedition 336," in Proc IODP, 336, eds K. J. Edwards, W. Bach, A. Klaus, and The Expedition 336 Scientists (Tokyo: Integrated Ocean Drilling Program Management International, Inc.).

Hjelmso, M. H., Hansen, L. H., Baelum, J., Feld, L., Holben, W. E., and Jacobsen, C. S. (2014). High-resolution melt analysis for rapid comparison of bacterial community compositions. Appl. Environ. Microbiol. 80, 3568-3575. doi: 10.1128/AEM.03923-13

Huber, J. A., Johnson, H. P., Butterfield, D. A., and Baross, J. A. (2006). Microbial life in ridge flank crustal fluids. Environ. Microbiol. 8, 88-99. doi: 10.1111/j.1462-2920.2005.00872.x

Hugenholtz, P., Pitulle, C., Hershberger, K. L., and Pace, N. R. (1998). Novel division level bacterial diversity in a Yellowstone hot spring. J. Bacteriol. 180, 366-376.

Jørgensen, S. L., Thorseth, I. H., Pedersen, R. B., Baumberger, T., and Schleper, C. (2013). Quantitative and phylogenetic study of the Deep Sea Archaeal Group in sediments of the Arctic mid-ocean spreading ridge. Front. microbiol. 4:229. doi: 10.3389/fmicb.2013.00299

Kruber, C., Thorseth, I. H., and Pedersen, R. B. (2008). Seafloor alteration of basaltic glass: textures, geochemistry, and endolithic microorganisms. Geochem. Geophys. Geosyst. 9:Q12002. doi: 10.1029/2008gc002119

Lanzen, A., Jorgensen, S. L., Huson, D. H., Gorfer, M., Grindhaug, S. H., Jonassen, I., et al. (2012). CREST-classification resources for environmental sequence tags. PLoS ONE 7:e49334. doi: 10.1371/journal.pone.0049334

Lee, M. D., Walworth, N. G., Sylvan, J. B., Edwards, K. J., and Orcutt, B. N. (2015). Microbial communities on seafloor basalts at Dorado Outcrop reflect level of alteration and highlight global lithic clades. Front. Microbiol. 6:1470. doi: 10.3389/fmicb.2015.01470

Lever, M. A., Alperin, M., Engelen, B., Inagaki, F., Nakagawa, S., Steinsbu, B. O., et al. (2006). Trends in basalt and sediment core contamination during IODP Expedition 301. Geomicrobiol. J. 23, 517-530. doi: 10.1080/01490450600897245

Lever, M. A., Rouxel, O., Alt, J. C., Shimizu, N., Ono, S., Coggon, R. M., et al. (2013). Evidence for microbial carbon and sulfur cycling in deeply buried ridge flank basalt. Science 339, 1305-1308. doi: 10.1126/science. 1229240

Lusk, R. W. (2014). Diverse and widespread contamination evident in the unmapped depths of high throughput sequencing data. PLOS ONE 9:e110808. doi: 10.1371/journal.pone.0110808

Lysnes, K., Torsvik, T., Thorseth, I. H., and Pedersen, R. B. (2004). "Microbial populations in ocean floor basalt: results from ODP Leg 187," in Proceedings of the Ocean Drilling Program, Scientific Results, Vol. 187, eds R. B. Pedersen, D. M. Christie, and D. J. Miller (College Station, TX: Ocean Drilling Program), 1-27. doi: 10.2973/odp.proc.sr.187.203.2004

Mason, O. U., Nakagawa, T., Rosner, M., Van Nostrand, J. D., Zhou, J., Maruyama, A., et al. (2010). First investigation of the microbiology of the deepest layer of ocean crust. PLOS ONE 5:e15399. doi: 10.1371/journal.pone.0015399

Meyer, J. L., Jaekel, U., Tully, B. J., Glazer, B. T., Wheat, C. G., Lin, H.-T., et al. (2016). A distinct and active bacterial community in cold oxygenated fluids circulating beneath the western flank of the Mid-Atlantic ridge. Sci. Rep. 6:22541. doi: 10.1038/srep22541

Nigro, L. M., Harris, K., Orcutt, B. N., Hyde, A., Clayton-Luce, S., Becker, K., et al. (2012). Microbial communities at the borehole observatory on the Costa Rica Rift flank (Ocean Drilling Program Hole 896A). Front. Microbiol. 3:232. doi: 10.3389/fmicb.2012.00232
Orcutt, B. N., Bach, W., Becker, K., Fisher, A. T., Hentscher, M., Toner, B. M., et al. (2011). Colonization of subsurface microbial observatories deployed in young ocean crust. ISME J. 5, 692-703. doi: 10.1038/ismej.2010.157

Orcutt, B. N., and Edwards, K. J. (2014). "Life in the ocean crust: lessons from subseafloor laboratories," in Earth and Life Processes Discovered from Subseafloor Environments: A Decade of Science Achieved by the Integrated Ocean Drilling Program (IODP), Vol. 7, eds R. Stein, D. Blackman, K. F. Inagaki, and H.-C. Larsen (Amsterdam: Elsevier), 175-196.

Orcutt, B. N., Sylvan, J. B., Knab, N. J., and Edwards, K. J. (2011). Microbial ecology of the dark ocean above, at, and below the seafloor. Microbiol. Mol. Biol. Rev. 75, 361-422. doi: 10.1128/MMBR.00039-10

Orcutt, B. N., Sylvan, J. B., Rogers, D., Delaney, J., Lee, R. W., and Girguis, P. R. (2015). Carbon fixation by basalt-hosted microbial communities. Front. Microbiol. 6:904. doi: 10.3389/fmicb.2015.00904

Orcutt, B. N., Wheat, C. G., Rouxel, O., Hulme, S., Edwards, K. J., and Bach, W. (2013). Oxygen consumption rates in subseafloor basaltic crust derived from a reaction transport model. Nat. Commun. 4:2539. doi: 10.1038/ ncomms3539

Sakata, K., Yabuta, H., Ikehara, M., and Kondo, T. (2015). “Data report: carbon content and isotopic composition of basalts and sediments in North Pond, Expedition 336," in Proc IODP, Vol. 336, eds K. J. Edwards, W. Bach, A. Klaus, and the Expedition 336 Scientists (Tokyo: Integrated Ocean Drilling Program Management International, Inc.), 1-8. doi: 10.2204/iodp.proc.336.203.2015

Salter, S. J., Cox, M. J., Turek, E. M., Calus, S. T., Cookson, W. O., Moffatt, M. F., et al. (2014). Reagent and laboratory contamination can critically impact sequence-based microbiome analyses. BMC Biol. 12:87. doi: 10.1186/s12915014-0087-z

Santelli, C. M., Banerjee, N., Bach, W., and Edwards, K. J. (2010). Tapping the subsurface ocean crust biosphere: low biomass and drilling-related contamination calls for improved quality controls. Geomicrobiol. J. 27, 158-169. doi: 10.1080/01490450903456780

Santelli, C. M., Orcutt, B. N., Banning, E., Bach, W., Moyer, C. L., Sogin, M. L., et al. (2008). Abundance and diversity of microbial life in ocean crust. Nature 453, U653-U657. doi: 10.1038/nature06899

Schrenk, M. O., Huber, J. A., and Edwards, K. J. (2010). Microbial provinces in the subseafloor. Annu. Rev. Mar. Sci. 2, 279-304. doi: 10.1146/annurev-marine120308-081000

Spang, A., Saw, J. H., Jorgensen, S. L., Zaremba-Niedzwiedzka, K., Martijn, J., Lind, A. E., et al. (2015). Complex archaea that bridge the gap between prokaryotes and eukaryotes. Nature 521, 173-179. doi: 10.1038/nature 14447

Stoddard, S. F., Smith, B. J., Hein, R., Roller, B. R. K., and Schmidt, T. M. (2015). rrnDB: improved tools for interpreting rRNA gene abundance in bacteria and archaea and a new foundation for future development. Nucleic Acids Res. 43, D593-D598. doi: 10.1093/nar/gku1201

Storrie-Lombardi, M. C., and Fisk, M. R. (2004). Elemental abundance distributions in suboceanic basalt glass: evidence of biogenic alteration. Geochem. Geophys. Geosys. 5:Q10005. doi: 10.1029/2004gc 000755

Thorseth, I. H., Pedersen, R. B., and Christie, D. M. (2003). Microbial alteration of 0-30-Ma seafloor and sub-seafloor basaltic glasses from the Australian Antarctic Discordance. Earth Planet. Sci. Lett. 215, 237-247. doi: 10.1016/S0012-821X(03)00427-8

Thorseth, I. H., Torsvik, T., Furnes, H., and Muehlenbachs, K. (1995). Microbes play an important role in the alteration of oceanic crust. Chem. Geol. 126, 137-146. doi: 10.1016/0009-2541(95)00 114-8

Torsvik, T., Furnes, H., Muehlenbachs, K., Thorseth, I. H., and Tumyr, O. (1998). Evidence for microbial activity at the glass-alteration interface in oceanic basalts. Earth Planet. Sci. Lett. 162, 165-176. doi: 10.1016/S0012821X(98)00164-2

Walsh, E. A., Kirkpatrick, J. B., Rutherford, S. D., Smith, D. C., Sogin, M., and D'Hondt, S. (2016). Bacterial diversity and community composition from seasurface to subseafloor. ISME J. 10, 979-989. doi: 10.1038/ismej. 2015.175

Wheat, C. G., Jannasch, H. W., Kastner, M., Plant, J. N., and DeCarlo, E. H. (2003). Seawater transport and reaction in upper oceanic basaltic basement: 
chemical data from continuous monitoring of sealed boreholes in a ridge flank environment. Earth Planet. Sci. Lett. 216, 549-564. doi: 10.1016/S0012$821 \mathrm{X}(03) 00549-1$

Conflict of Interest Statement: The authors declare that the research was conducted in the absence of any commercial or financial relationships that could be construed as a potential conflict of interest.
Copyright (๑) 2016 Jørgensen and Zhao. This is an open-access article distributed under the terms of the Creative Commons Attribution License (CC BY). The use, distribution or reproduction in other forums is permitted, provided the original author(s) or licensor are credited and that the original publication in this journal is cited, in accordance with accepted academic practice. No use, distribution or reproduction is permitted which does not comply with these terms. 